\title{
SYNTHESIS OF PINONIC ACID NEW DERIVATIVES
}

\author{
Alexandru Gudima, Liudmila Vlad, Fliur Macaev* \\ Institute of Chemistry of the Academy of Sciences of the Republic of Moldova, \\ Academy str. 3, MD-2028, Chisinau, Republic of Moldova \\ Tel +373-22-739-754, Fax+373-22-739-954,*E-mail: flmacaev@cc.acad.md
}

\begin{abstract}
The method for synthetising new derivatives of the pinonic acid using, at the key step, the reaction of condensation with epichlorohydrin, has been elaborated. It has been shown that, in the presence of catalytic amount of tetrabutylammonium chloride, the reaction is directed towards the formation of etherchlorohydrin, which, later on, is easily transformed into epoxides as well as chloromethyldiketones with good overall yield.
\end{abstract}

Keywords: pinonic acid, chlorohydrin, epoxide.

\section{Introduction}

Chlorohydrins, epoxides as well as 2-chloromethylketones are widely used in synthetising various, practically important substances. One of the perspective directions towards obtaining such type compounds in an optically active form may involve the use of pinonic acid 2 [1] as chiral matrix.

\section{Results and discussions}

To realize this approach, we have investigated the possibility of regioselective transformation of acid $\mathbf{2}$ using epichlorohydrin 3.

Heating of $\mathbf{2}$ in $\mathbf{3}$ leads to an unidentified complex mixture of products. The probable reason of this phenomenon is the proceeding of the reaction of oxirane cycle disclosure according to both $\mathrm{Sn} 2$ and Sn1-mechanisms.

It has been established that the addition of catalytic quantities of tetrabutylammonium chloride directs the reaction towards the formation of chlorohydrins $\mathbf{4}$ according to the scheme.

Scheme<smiles>CC(=O)[C@H](CC(=O)O)[C@@H](CC(=O)O)C(C)(C)C(=O)ON(C)Br</smiles>

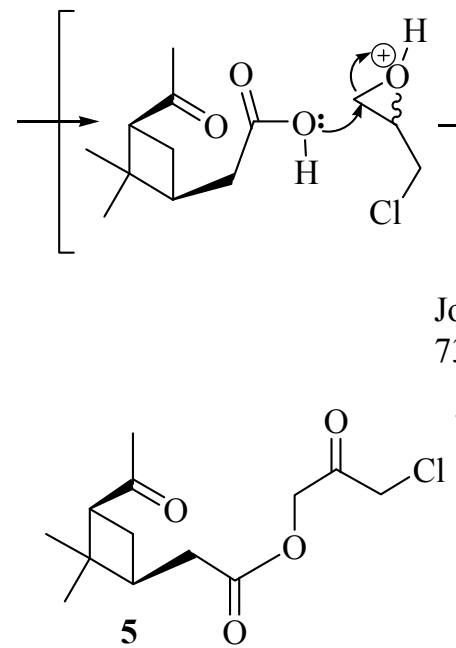<smiles>CC(=O)[C@H]1C[C@@H](CC(=O)OC[C@H](O)CCl)C1(C)C</smiles>

Jones $73 \%$
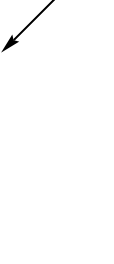<smiles>CC(=O)[C@H]1C[C@@H](CC(=O)OCC2CO2)C1(C)C</smiles>

In IR-spectrum of mixture 4 can observe characteristic bands of carbonyl group of methylketone and ester groups at 1715 and $1770 \mathrm{~cm}^{-1}$, respectively. The spectrum is added by signals at $770 \mathrm{~cm}^{-1}-(\mathrm{C}-\mathrm{Cl})$ and $3600 \mathrm{~cm}^{-1}(\mathrm{OH})$. A distinctive feature of NMR spectra of diastereomers 4 is the doubling of all peaks due to the fact that the initial epichlorohydrin 3 represented a mixture of stereo isomers. 
Alcohols 4 are oxidized by Jones's reagent into ketone 5. Its structure is confirmed by the availability of maximum of two carbonyl and carboxylic ester groups $\left(1715,1735 \mathrm{~cm}^{-1}\right)$ in the IR-spectrum, as well as of characteristic signals of protons of four methylene groups, of one methylketone and two methyls of gem-dimethyl groups in the ${ }^{1} \mathrm{H}$ NMR-spectrum.

In comparison with carbon spectrum of initial 4 , the signal of the carbon atom of the formed carbonyl group and the absence of the carbon atom signal at hydroxyl group in the area of $69.37 \mathrm{ppm}$, is observed in the ${ }^{13} \mathrm{C}$ NMR-spectrum of product 5 in the weak field area (195.65 ppm).

Boiling of chlorohydrin 4 in $\mathrm{KOH}$ ethanol solution leads, with $68 \%$ yield, to oxide 6 whose structure results from spectral data. Present in its IR-spectrum are the frequencies characteristic for keto-, carboxylic ester and oxirane groups, while in the ${ }^{1} \mathrm{H}$ NMR-spectrum available are the three protons signals of gem-dimethyl and acetyl groups. Besides, available in the spectrum are multiplet signals of the protons of oxirane fragment connected with carboxyl group.

\section{Conclusions}

Thus, it has been shown that utilization of tetrabutylammonium chloride allows performing the chemo- and regioselective functionalization of pinonic acid $\mathbf{2}$ up to chlorohydrins, later converted into 2-chlorodiketone and epoxides. The utilizing the synthesized compounds for preparing the practically important optically active substances are now under investigation.

\section{Experimental}

All the used solvents were of reagent quality, and all commercial reagents have been used without additional purification. Removal of all solvents has been carried out under reduced pressure. Analytical TLC plates were Silufol ${ }^{\circledR}$ UV-254 (Silpearl on aluminium foil, Czecho-Slovakia). Melting points has been determined on the heating table "Boetius" and not corrected. IR spectra have been recorded on a Specord 75 IR instrument. ${ }^{1} \mathrm{H}$ and ${ }^{13} \mathrm{C}$ NMR spectra have been recorded for $\mathrm{CDCl}_{3} 2-3 \%$ solution on a Bruker $\mathrm{AC}-80(80$ and $20 \mathrm{MHz})$.

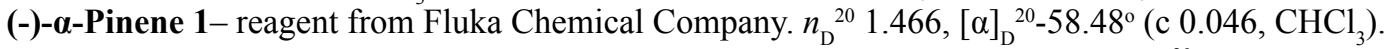

Acid 2 has been synthesized from 1 by method [1]. M.p. $64-67^{\circ} \mathrm{C}$ from hexane. $[\alpha]_{\mathrm{D}}{ }^{20}-74.03^{\circ}\left(\mathrm{c} 0.0199, \mathrm{CHCl}_{3}\right)$.

Preparation of 3-chloro-2-hydroxypropyl-2-[(1S,3R)-3-acetyl-2,2-dimethylcyclobutyl]acetate 4.

$5 \mathrm{~g}(27 \mathrm{mmol})$ of acid 2 and $0.1 \mathrm{~g}$ of tetrabutylammonium chloride in $5 \mathrm{ml}$ of epichlorohydrin 3 has been kept during 1 hour at $120^{\circ} \mathrm{C}$. Then, the excess of epichlorohydrin has been distilled off in vacuum. The residue has been dissolved in $100 \mathrm{ml}$ of ether, washed with saturated solution $\mathrm{NaCl}(3 \times 20 \mathrm{ml})$, dried over $\mathrm{Na}_{2} \mathrm{SO}_{4}$, distilled off the ether and obtained $5.9 \mathrm{~g}$ yellowish oil-like product 7:3 mixture of diastereoisomers 4 . The yield was $79 \%$. IR ( $\left./ \mathrm{cm}^{-1}\right): 770(\mathrm{C}-$ $\left.\mathrm{Cl}), 1375,1380 \mathrm{CMe}_{2}\right), 1715\left(\mathrm{COCH}_{3}\right), 1740\left(\mathrm{COOCH}_{2}\right), 3600(\mathrm{OH}) .{ }^{1} \mathrm{H} \mathrm{NMR}$ of the major isomer $(\delta, \mathrm{ppm}, J / \mathrm{Hz}): 0.79$, $1.21 \mathrm{~s}, \mathrm{~s}\left(6 \mathrm{H}, \mathrm{CMe}_{2}\right), 1.93 \mathrm{~s}\left(3 \mathrm{H}, \mathrm{COCH}_{3}\right), 1.70-2.89 \mathrm{~m}\left(6 \mathrm{H},{ }^{7} \mathrm{CH}_{2},{ }^{4} \mathrm{CH}_{2},{ }^{5} \mathrm{CH},{ }^{1} \mathrm{CH}\right), 3.02-3.12 \mathrm{~m}(1 \mathrm{H}, \mathrm{OH}), 3.44-4.25 \mathrm{~m}$ $\left(5 \mathrm{H}, \mathrm{COOCH}_{2}, \mathrm{CH}-\mathrm{OH}, \mathrm{CH}_{2}-\mathrm{Cl}\right) .{ }^{13} \mathrm{C}$ NMR of the major isomer $(\delta, \mathrm{ppm}): 207.62\left({ }^{2} \mathrm{C}\right), 172.65\left({ }^{3} \mathrm{C}\right), 69.37(\mathrm{C}-\mathrm{OH}), 65.02$ $\left(\mathrm{COO}_{\mathrm{CH}}\right), 54.04\left({ }^{1} \mathrm{C}\right), 45.66(\mathrm{C}-\mathrm{Cl}), 43.14\left({ }^{6} \mathrm{C}\right), 37.82\left({ }^{5} \mathrm{C}\right), 34.76\left({ }^{4} \mathrm{C}\right), 30.06\left({ }^{10} \mathrm{C}\right), 22.91\left({ }^{8} \mathrm{C},{ }^{9} \mathrm{C}\right), 17.22\left({ }^{7} \mathrm{C}\right)$. Found, $\%$ : C 56.34, H 7.58. $\mathrm{C}_{13} \mathrm{H}_{21} \mathrm{ClO}_{4}$. Calculated, \%: C 56.42, $\mathrm{H} 7.65$.

Preparation of (-)-3-chloro-2-oxopropyl-2-[(1S,3R)-3-acetyl-2,2-dimethylcyclobutyl]acetate 5.

Jones's reagent prepared from $7 \mathrm{~g} \mathrm{CrO}_{3}, 6 \mathrm{ml} \mathrm{H}_{2} \mathrm{SO}_{4}$ and $10 \mathrm{ml} \mathrm{H}_{2} \mathrm{O}$ has been added to solution of $2.8 \mathrm{~g} \mathrm{(10}$ $\mathrm{mmol}$ ) of 4 in $15 \mathrm{ml}$ acetone at by drops stirring, and has been stirred for 3 hours. Then, $30 \mathrm{ml}$ of $i$-propyl alcohol has been added and left overnight. The following day, the mixture has been extracted by means of diethyl ether $(5 \times 50 \mathrm{ml})$, the extract has been washed with $\mathrm{NaNCO}_{3}$ solution $(2 \times 30 \mathrm{ml})$ and with saturated $\mathrm{NaCl}$ solution $(2 \times 30 \mathrm{ml})$, dried over $\mathrm{Na}_{2} \mathrm{SO}_{4}$, distilled off the ether and have obtained $2.01 \mathrm{~g}$ yellow oil-like product 5 . The yield was $73 \%$. $[\alpha]_{\mathrm{D}}{ }^{20}-14.09^{\circ}(\mathrm{c}$ $\left.0.1, \mathrm{CHCl}_{3}\right)$. IR $\left.\left(\mathrm{v} / \mathrm{cm}^{-1}\right): 760(\mathrm{C}-\mathrm{Cl}), 1380,1385 \mathrm{CMe}_{2}\right), 1715(\mathrm{C}=\mathrm{O}), 1735\left(\mathrm{COOCH}_{2}\right) .{ }^{1} \mathrm{H} \mathrm{NMR}(\delta, \mathrm{ppm}, J / \mathrm{Hz}): 1.16$, $1.24 \mathrm{~s}, \mathrm{~s}\left(6 \mathrm{H}, \mathrm{CMe}_{2}\right), 2.05 \mathrm{~s}\left(3 \mathrm{H}, \mathrm{COCH}_{3}\right), 1.33-2.90 \mathrm{~m}\left(6 \mathrm{H},{ }^{7} \mathrm{CH}_{2},{ }^{4} \mathrm{CH}_{2},{ }^{5} \mathrm{CH},{ }^{1} \mathrm{CH}\right), 4.18 \mathrm{~m}\left(2 \mathrm{H}, \mathrm{CH}_{2} \mathrm{Cl}\right), 4.89 \mathrm{~m}(2 \mathrm{H}$, $\left.\mathrm{COOCH}_{2}\right) \cdot{ }^{13} \mathrm{C} \mathrm{NMR}(\delta, \mathrm{ppm}): 208.33\left({ }^{2} \mathrm{C}\right), 195.65\left(\mathrm{O}=\underline{\mathrm{C}}-\mathrm{CH}_{2}\right), 172.87\left({ }^{3} \mathrm{C}\right), 64.24\left(\mathrm{COOCH}_{2}\right), 53.87\left({ }^{1} \mathrm{C}\right), 46.01(\mathrm{C}-$ $\mathrm{Cl}), 43.14\left({ }^{6} \mathrm{C}\right), 37.64\left({ }^{5} \mathrm{C}\right), 34.33\left({ }^{4} \mathrm{C}\right), 29.99\left({ }^{10} \mathrm{C}\right), 22.83\left({ }^{8} \mathrm{C},{ }^{9} \mathrm{C}\right), 17.11\left({ }^{7} \mathrm{C}\right)$. Found, \%: C 56.80, $\mathrm{H} 7.02 . \mathrm{C}_{13} \mathrm{H}_{19} \mathrm{ClO}_{4}$. Calculated, \%: C 56.83, H 6.97.

Preparation of 2-oxiranylmethyl-2-[(1S,3R)-3-acetyl-2,2-dimethylcyclobutyl]acetate 6.

Solution of $1.35 \mathrm{~g}(4.9 \mathrm{mmol})$ of 5 and $0.41 \mathrm{~g}(7.3 \mathrm{mmol})$ of $\mathrm{KOH}$ in $20 \mathrm{ml}$ of EtOH have been boiled under refluxing during 5 hours. Then, the ethanol has been distilled off, the residue has been diluted with $20 \mathrm{ml}$ of water and extracted with $\mathrm{CHCl}_{3}(5 \times 10 \mathrm{ml})$. The extract has been washed with $10 \mathrm{ml}$ of saturated $\mathrm{NaCl}$ solution, dried over $\mathrm{Na}_{2} \mathrm{SO}_{4}$, chloroform has been distilled off and $0.8 \mathrm{~g}$ of yellow oil-like 7:3 mixture of diastereoisomers 6 have been obtained. The yield was 68\%. IR $\left(\mathrm{v} / \mathrm{cm}^{-1}\right): 1380,1385\left(\mathrm{CMe}_{2}\right), 1710\left(\mathrm{COCH}_{3}\right), 1735\left(\mathrm{COOCH}_{2}\right), 3040\left(\right.$ epoxi). ${ }^{1} \mathrm{H} \mathrm{NMR}$ of major isomer $(\delta$, ppm, $\mathrm{J} / \mathrm{Hz}): 1.05,1.14 \mathrm{~s}, \mathrm{~s}\left(6 \mathrm{H}, \mathrm{CMe}_{2}\right), 1.90 \mathrm{~s}\left(3 \mathrm{H}, \mathrm{COCH}_{3}\right), 1.79-2.74 \mathrm{~m}\left(8 \mathrm{H}^{7}{ }^{7} \mathrm{CH}_{2},{ }^{4} \mathrm{CH}_{2},{ }^{5} \mathrm{CH}_{,}{ }^{1} \mathrm{CH}_{1} \mathrm{CH}_{2}\right.$ epoxi), 3.35-3.44 m (1H, CH epoxi), 3.83-4.10 m (2H, $\left.\mathrm{CO}_{2} \mathrm{CH}_{2}\right)$. Found, \%: $\mathrm{C} 64.83, \mathrm{H} \mathrm{8.42.} \mathrm{C}_{13} \mathrm{H}_{20} \mathrm{O}_{4}$. Calculated, \%: C 64.98, H 8.39.

\section{References}

[1]. Gudima, A. Research in chemistry: achievements and prospects. Chişinău, 2003, V.II, p. 103-105. 